\title{
DIASPORA ROMÂNEASCĂ - REALITATE PROEMINENTĀ ŞI PROVOCARE MISIONARĂ
}

\author{
Florin-Spiridon Croitoru*
}

\begin{abstract}
One of the most dynamic works of Romanian Orthodox Church in the last 25 years is spiritual care for Romanians working abroad. Sensitive to the pastoral needs of the Romanian Orthodox believers temporarily or permanently established in the countries majority unorthodox, Romanian Patriarchate organized new Orthodox dioceses and parishes in different countries, to ensure to the Romanian believers religious assistance and an appropriate pastoral care, an ethos of life similar of the country, with traditions, habits, religious services and community organization.
\end{abstract}

Keywords: Diaspora, mission, pastoral care

O componentă a evoluției și dinamicii populației în perioada post decembristă, pe lângă natalitate şi mortalitate, este migrația. Ea reprezintă deplasarea unui număr de oameni între societăţi şi în interiorul acestora sau dincolo de granițele simbolice sau politice, spre noi comunități şi arii rezidențiale. Migrația este un proces social care a influențat şi influențează profund societatea românească contemporană, milioane de cetățeni români trăind personal acest fenomen. Este tot mai evident faptul că umanitatea a intrat într-o nouă epocă a migrațiilor ${ }^{1}$. Deşi aparent, fenomenul migrației poate fi privit la nivelul unui act individual, ca o simplă decizie pe care o persoană o ia în legătură cu locul de muncă sau de domiciliu dorit, în această decizie fiind implicate determinări multiple, asociate cu starea sociocultural-economică a localităților, a familiei, a parohiei, a persoanei

\footnotetext{
${ }^{*}$ Rev. PhD

${ }^{1}$ Remus Gabriel Anghel, Istvan Horvath - Coord, Sociologia Migratiei. Teorii şi studii de caz româneşti, Ed. Polirom, Iaşi, 2009, p. 14.
} 
în cauză şi a societăţii în general. Datorită acestor conexiuni multiple în care este implicată, migrația poate fi considerată un fenomen social total. ${ }^{2}$

Migrația românească, ce se conturează în sistemul global al migrației ca un produs automat al dezvoltării capitalismului, în contextul dependențelor şi relațiilor economice la nivel globalşi a includerii unor regiuni periferice ale lumii în organizarea economică globală ${ }^{3}$ este, aşa cum putem constata, foarte dinamică şi reprezintă una dintre principalele migrații spre vestul Europei, ce implică, atât pentru România, cât şi pentru țările de destinații, o serie de provocări, probleme, riscuri şi abordări diferite. Fenomenul emigraței este unul proeminent, deşi situația economică a României s-a ameliorat în timp, emigrația în Uniunea Europeană mai ales a continuat în noul mileniu. Chiar şi în deceniul trecut, în ciuda creşterii progresive a cererii interne de forță de muncă, segmente largi ale populației şi-au exprimat dorința de a pleca. Potrivit unei anchete din 2006, 9\% din populația adultă a României intenționa să lucreze în străinătate în 2007, iar în cadrul grupului de vârstă 18-24 de ani, rata migranților potențiali se ridica la $23 \%{ }^{4}$

Europa a început să se confrunte cu un fluxuri migratoare de proporții dupa anii ' 90 , căderea comunismului prevestind un exod de proporții dinspre est spre vest. Ea a primit, o dată cu forța de muncă ieftină şi mai puține probleme legate de diferențele rasiale sau culturale. Extinderea Uniunii Europene către est în anii 2004 şi 2007, cu anumite restricții legate de circulația forței de muncă, a transformat emigrația într-un fenomen de mobilitate teritorială regională către țări ce şi-au afirmat tot mai mult poziția de spațiu de destinație. ${ }^{5}$ Românii au răspuns din plin acestei nevoi europene de imigrație.

\footnotetext{
${ }^{2}$ Dumitru Sandu, Sociologia Tranziției, Ed. Staff, București, 1996, p.204.

${ }^{3}$ Remus Gabriel Anghel, Istvan Horvath - Coord, Op. Cit., p. 25.

${ }^{4}$ Istvan Horvath, Aspecte ale culturii migratiei în România, în Remus Gabriel Anghel, Istvan Horvath (coord.), Op. Cit., p. 157.

5 Monica Șerban, Migrație, în „Sociologie”, vol. Coordonat de Lazăr Vlasceanu, Ed. Polirom, Iaşi, 2011, p. 803.
} 
Migrația poate fi desfăcută în două aspecte distincte: imigrația, ce se referă la numărul oamenilor care intră în țară într-o perioadă fixă de timp şi emigrația, care se referă la numărul oamenilor care se mută în afara granițelor unei țări, definitiv sau temporar, într-un timp dat. Aceste elemente, combinate, produc migrația netă, care este câştigul sau pierderea de populație dintr-o țară datorită migrației. În plus, există, bineînțeles, şi o migrație internă sau o deplasare a oamenilor de la o zonă la alta în interiorul aceleiaşi țări (fluxurile satoraş, oraş-oraş sau oraş-sat) ${ }^{6}$, precum şi o migrație confesională, dinspre bisericile istorice către denoninaţiunile neo-protestante. Dimensiunea pe care vom insista în abordarea noastră este emigrația, fenomen care a înregistrat o explozie în perioada 2002 - 2007, o dată cu liberalizarea regimului vizelor pentru Spațiul Schengen şi care a provocat reacția Patriarhiei Române înspre organizarea slujirii disporei româneşti, dezvoltate foarte mult în ultimii douăzeci de ani.

Migrația forței de muncă se regăseşte în agenda diverselor instituții, printre care se numără şi Patriarhia Română, dar şi în atenţia imaginarului naţional şi a simplului cetăţean. $\mathrm{Ca}$ urmare a liberalizării circulației forței de muncă în spațiul European, fenomenul migrației forței de muncă a luat amploare, generând şi un fenomen diasporic evident - fenomene specifice construcției europene şi proceselor globalizării. Experiența delocalizării a devenit o realitate curentă, iar mobilitatea a fost încurajată, pe de o parte, de situația economică românească, iar pe de altă parte, de realitate economică şi de repertoriul de oportunități la nivel individual şi familial, pe care societăţile vest-europene le-au oferit.

Din punct de vedere religios, termenul de diaspora desemnează un concept biblic bine cunoscut, cu referire la diaspora iudaică din antichitate. În Noul Testament se face referire la o aşa numită diasporă a primilor creştini: „Deci au zis iudeii, între ei: unde are să se ducă Acesta, ca noi să nu-L găsim? Nu cumva va merge la cei împrăştiați printre elini şi va învăța pe elini? (Ioan 7, 35); „Iacov, robul lui Dumnezeu şi al Domnului Iisus Hristos, celor douăsprezece

${ }^{6}$ Mircea Agabrian, Sociologie Generală, p. 274. 
seminții, care sunt în împrăştiere, salutare!” (Iacov 1, 1); „Petru, apostol al lui Iisus Hristos, către cei ce trăiesc împrăştiați printre străini, în Pont, în Galatia, în Capadocia, în Asia și în Bitinia". (1 Petru 1,1$)^{7}$ In zilele noastre, diaspora nu mai poate fi analizată doar ca o categorie istorică referitoare la migranții care îşi păăseau țara de origine pentru a se refugia din motive politice, economice sau religioase într-o altă țară. Termenul de diaspora a dobândit o accepțiune mai largă, în contextul globalizării, al mobilității transnaţionale şi al expansiunii noilor tehnologii de comunicare. Diaspora defineşte mai degrabă comunităţi şi indivizi care se află pentru o perioadă de timp într-o țară de destinație, practică unul sau mai multe tipuri de mobilitate (profesională, economică, culturală, religioasă etc.), îşi creează în țara respectivă rețele şi afilieri, însă, în acelaşi timp, nu sunt deconectaţi de țara de origine. ${ }^{8}$

Una dintre cele mai importante şi mai dinamice lucrări ale Bisericii Ortodoxe Române în ultimii ani este grija spirituală pentru românii plecaţi în străinătate. Ea nu poate şi nu are voie să îşi părăsească membrii în deciziile lor şi nici să rămână insensibilă la nevoile pastorale ale credincioşilor ortodocşi români stabiliți temporar sau definitiv în țări neortodoxe. De aceea, s-au organizat noi eparhii ortodoxe şi au luat ființă parohii în diferite țări ale lumii, pentru a asigura credincioşilor români asistenţă religioasă şi o pastorație corespunzătoare, un ethos de viață cotidiană şi socială apropiat celui din țară, cu tradiții, obiceiuri, slujbe şi organizare comunitară, ce poate fi trăit ca realitate cotidiană în țările unde locuiesc şi stimulează sensibilitatea identitară a migrantului.

Diaspora Bisericii Ortodoxe Române a luat naştere în două moduri:

${ }^{7}$ John Meyendorff, Vision of Unity, SVS Press, New York, 1987, p. 139.

8 Camelia Beciu, Diaspora şi experiența transnatională. Practice de mediatizare in presa românească, „Revista Română de Sociologie”, serie nouă, anul XXIII, București, 2012, nr. 1-2, p. 50. 
1.

Prin stabilirea dureroasă a noilor frontiere, după cele două războaie mondiale, un număr foarte mare de români rămânând în afara granițelor de vest şi de sud ale României;

2. Prin emigrație, în mai multe valuri, cele mai consistente fiind după revoluția din anul 1989.

Chiar şi în perioada 1948-1989, Patriarhia Română s-a îngrijit de românii din diaspora, în pofida greutăţilor impuse de regimul comunist. Sub îndrumarea Sfântului Sinod, a fost făcută o acțiune de reorganizare a unităţilor din diaspora, au fost trimişi preoți şi cântăreți şi s-au amenajat spații liturgice.

Deşi autoritățile comuniste din România le-au interzis orice legătură cu țara, credincioşii ortodocşi români ce trăiau departe de țară s-au organizat în două eparhii: Arhiepiscopia Misionară Ortodoxă Română din Statele Unite şi Canada, cu sediul la Detroit şi Arhiepiscopia Misionară Ortodoxă Română pentru Europa Centrală şi Occidentală, cu sediul la Paris. Pe lângă acestea, s-a reuşit constituirea unor parohii în unele capitale europene, de mare importanță în viaţa diasporei româneşti (Londra - 1964, Stockholm 1971, Melbourne - 1972, Madrid şi Milano - 1975).

În prezent, diaspora ortodoxă românească este organizată în trei mitropolii (Mitropolia Basarabiei, Mitropolia Ortodoxă Română a Europei Occidentale şi Meridionale şi Mitropolia Ortodoxă Română a Germaniei, Europei Centrale şi de Nord), o arhiepiscopie (Arhiepiscopia Ortodoxă Română a celor două Americi), şase episcopii ( Episcopia Daciei Felix, Episcopia Ortodoxă Română din Ungaria, Episcopia Ortodoxă Română a Australiei şi Noii Zeelande, Episcopia Ortodoxă Română a Italiei, Episcopia Ortodoxă Română a Spaniei şi Portugaliei, Episcopia Ortodoxă a Europei de Nord) şi trei eparhii reînființate în Republica Moldova, încă nefuncționale.

Pe lângă acestea, există şi structuri bisericeşti ale comunităţilor româneşti din afara granițelor țării: aşezămintele româneşti de la Locurile Sfinte - Ierusalim, Iordan şi Ierihon, parohia ortodoxă română de la Sofia (Bulgaria), parohiile ortodoxe române de la Tokyo şi Osaka-Nagoya (Japonia), aşezămintele româneşti din Sfântul Munte Athos - Podromu şi Lacu, comunitatea românească 
din Cipru, parohiile ortodoxe române din Istanbul, Johannesburg (Africa de Sud), Damasc (Siria) şi Brno (Cehia). ${ }^{9}$

Românii din jurul granițelor nu pot fi încadrați în categoria diaspora. Ei trăiesc pe vechi vetre româneşti, fiind autohtoni în nişte teritorii care, din cauza vicisitudinilor istorice, au rămas în afara granițelor actuale ale țării noastre. E vorba despre românii din Peninsula Balcanică, aromânii din Pind şi Hemus, din Valea Timocului şi Banatul Sârbesc, Macedonia, Bulgaria, Ungaria, Nordul Bucovinei, Basarabia şi Maramureşul istoric. O parte dintre ei, respectiv românii din Albania (fârşeroți, aproximativ 100.000), Grecia (aromânii din Pind şi Thesalia, aproximativ 200.000), Republica Macedonia (aromâni, aproximativ 80.000), Bosnia şi Herțegovina (istroromâni, aproximativ 500) la care se adaugă căteva sute de vlaho-morlaci din Croaia şi Slovenia, au fost uitạ̦i de autoritățile româneşti, iar, din cauza lipsei de dialog, de care au dat dovadă Bisericile Ortodoxe Surori din țările respective, nici Biserica Ortodoxă Română nu a putut să facă mare lucru. Există totuşi acțiuni de încurajare a asociațiilor culturale care desfăşoară activităţi de conservare etnică în acele zone, dar viitorul acestor comunități nu se întrevede foarte încurajator. ${ }^{10}$ Pentru românii din Serbia (din provincia Voivodina, de pe Valea Timocului şi de pe Valea Moravei), unde comunitățile româneşti sunt numeroase şi mai bine organizate, autoritățile politice ale Românei, cât şi Biserica Ortodoxă Română se implică în sprijinirea identității lor, prin obținerea unor drepturi religioase legitime, trimiterea de preoți, şi asigurarea de contribuții la salariile lor, donarea de cărți şi de obiecte de cult, oferirea de burse pentru tinerii ce doresc să facă studii de teologie în

\footnotetext{
${ }^{9}$ Autocefalie şi comuniune; Biserica Ortodoxă Română în dialog şi cooperare externă (1885-2010), Ed. Basilica a Patriarhiei Române, Bucureşti, 2010, p. 420 .

${ }^{10}$ Pr. Ion Armași - Vartan, Biserica Ortodoxă Română în diaspora. Scurt istoric şi organizare actuală, Teză de doctorat, susținută la Facultatea de Teologie Ortodoxă „Justinian Patriarhul” din București în data de 22 noiembrie 2011, p. 29.
} 
România etc. ${ }^{11}$ Pentru românii din aceste zone, credința a fost şi rămâne elementul cel mai puternic pentru păstrarea, nu numai a identității religioase, ci şi a celei naționale, culturale şi lingvistice. „Păstrarea legăturilor cu țara-mamă le dădea speranța şi liniştea că se găsesc în permanentă comuniune spirituală cu comunitatea de care sau despărțit şi că, prin aceasta, se găsesc în comuniune cu întreaga Biserică."

Situaţia eparhiior şi parohiile ce deservesc diaspora românească, reactivate sau înființate după 1990 este următoarea:

Mitropolia Basarabiei. După proclamarea independenței Republicii Moldova în data de 27 august 1991, ca urmare a Actului Patriarhal şi Sinodal nr. 8090 / 19 decembrie 1992, Sfântul Sinod Permanent al B. O. R., în şedința din 19 decembrie 1992, a hotărât reactivarea Mitropoliei Basarabiei (cf. hot. nr. 8090/19 decembrie 1992).

Episcopia Daciei Felix a fost înființatăîn data de 28 ianuarie 1971, urmare a întrunirii Adunării clerului ortodox român din Voivodina. În şedinţa sa din 13-14 februarie 1997, Sfântul Sinod al B. O. R. a aprobat reactualizarea şi punerea în aplicare a Convenției privind poziția Bisericii Ortodoxe Române din Banatul iugoslav şi a Bisericii Ortodoxe Sârbe din Banatul românesc.

Episcopia Ortodoxă Română din Ungaria, cu sediul la Jula, a fost înființată la data de 27 martie 1946 pentru comunităţile ortodoxe româneşti din Ungaria, dar care a funcționat multă vreme ca un vicariat. A fost ridicată la rangul de episcopie de către Sfântului Sinod al B. O. R. în sedința din data de 4 Februarie 1999.

Episcopia Ortodoxă Română a Italiei, cu sediul la Roma, a fost înființtată prin hotărârea Sfântul Sinod al B. O. R. nr. 2707/2 iulie 2007.

${ }^{11}$ Ibidem, p. 30.

12 Alexandru Moraru, Biserica Ortodoxă Română intre anii 1885 - 2000. Bisercă. Națiune. Cultură, Vol III, Tom I, E.I.B.M.B.O.R., Bucureşti, 2006, p. 225. 
Episcopia Ortodoxă Română a Spaniei şi Portugaliei, cu sediul la Madrid, a fost înființată prin hotărârea Sfântul Sinod al B. O. R. cu numărul 4587/22 octombrie 2007.

Mitropolia Ortodoxă Română a Germaniei, Europei Centrale şi de Nord. În anul 1993, Sfântul Sinod, a aprobat înfiinţarea „Mitropoliei Ortodoxe Române pentru Germania şi Europa", pentru ca în anul 2002, titulatura să fie completată astfel: „Mitropolia Ortodoxă Română pentru Germania, Europa Centrală şi de Nord". Din anul 2008, titulatura acestei eparhii este „Arhiepiscopia Ortodoxă Română a Germaniei, Austriei şi Luxemburgului".

Episcopia Ortodoxă Română a Europei de Nord. Prin hotărârea nr. 4586/22 octombrie 2007, Sfântul Sinod al Bisericii Ortodoxe Române a aprobat înființarea şi organizarea Episcopiei Ortodoxe Române a Europei de Nord, cu sediul la Stockholm, ca eparhie sufragană a Mitropoliei Ortodoxe Române a Germaniei, Europei Centrale şi de Nord.

Arhiepiscopia Ortodoxă Română a celor două Americi. La inițiativa credincioşilor din America, Sfântul Sinod al B. O. R. a hotărât în anul 1930 crearea „Episcopiei Misionare Ortodoxe Române în America". În anul 1974, răspunzând noilor realități date de dimnesionarea diasporei locale, ea a fost ridicată la rang de arhiepiscopie, iar din anul 1991 titulatura acestei eparhii este "Arhiepiscopia Ortodoxă Română a celor două Americi".

Episcopia Ortodoxă Română a Australiei şi Noii Zeelande. În data de 22 octombrie 2007, Sfântul Sinod al B. O. R. a aprobat ridicarea Vicariatului pentru Australia şi Noua Zeelandă la rang de episcopie, cu titulatura Episcopia Ortodoxă Română a Australiei şi Noii Zeelande.

Așezămintele Româneşti din Sfântul Munte Athos (Prodromu, Lacu şi alte schituri sau chilii), deşi sunt în jurisdicția canonică a Patriarhiei Ecumenice, păstrează legături spirituale şi culturale cu Patriarhia Română şi sunt sprijinite material şi financiar din România. 
Aşezămintele româneşti din Țara Sfântă (Ierusalim, Iordan şi Ierihon) sunt dependente canonic şi financiar direct de Patriarhia Română.

\section{Comunitatea Ortodoxă Română din Cipru}

Comunitatea Ortodoxă din Cipru a fost înființată în anul 1995. Parohia şi funcționează în cadrul Alianței Românilor din Cipru pentru cele patru oraşe din zona grecească a Ciprului.

Parohia Ortodoxă Română din Istanbul a fost înființată în anul 2001.

Parohia Ortodoxă Română din Johannesburg, Africa de Sud a fost înființată în anul 2000. Din anul 2009, s-a deschis o nouă capelă pentru românii care locuiesc în Centurion-Johannesburg,

Parohia Ortodoxă Română Sfântul Gheorghe, din Tokio, Japonia s-a înființat prin decizia patriarhală nr. 11/2008. Parohia Ortodoxă Română Învierea Domnului, din Osaka-Nagoya, a fost înființată la început ca Misiune, prin decizia patriarhală nr. 13/2008 şi s-a constituit conform hotărârii Permanenței Consiliului Național Bisericesc, din data de 24 septembrie, temei nr. 6810/2008.

Parohia Ortodoxă Română din Damasc, Siria, a fost înființată în 4 martie 2009. ${ }^{13}$

Dacă înainte de 1990, doar 17 preoți slujeau în comunitățile româneşti din străinătate, aflate în jurisdicția Patriarhiei Orotodoxe Române, între anii 1990-2007, au fost numiţi 137 de preoți pentru parohiile înființate, în noile condiții de libertate şi de mobilitate europeană. După reorganizarea diasporei românești, începută în anul 2007 de către Patriarhul Daniel, peste 300 de preoți români au primit misiunea de a constitui parohii şi a se îngriji din punct de vedere spiritual de românii din diaspora. Pentru toți aceştia, Patriarhia Română asigură o contribuție la salarizare şi plata cotelor de asistență socială şi de sănătate. La ei se adaugă clericii plătiți din

\footnotetext{
${ }^{13}$ Autocefalie şi comuniune; Biserica Ortodoxă Română în dialog şi cooperare externă (1885-2010), Ed. Basilica a Patriarhiei Române, Bucureşti, 2010, p. 644.
} 
fondurile proprii ale eparhiilor ${ }^{14}$ şi cei peste 100 de clerici români de pe continentul american, care, deoarece legislația americană nu permite primirea de fonduri dintr-o altă țară, sunt sprijiniți de Patriarhia Română cu veşminte liturgice, cărți de cult şi obiecte bisericeşti. ${ }^{15}$

Cea mai mare parte a celor delocalizaţi sunt tineri şi mobili şi reprezintă în special specialişti sau forță de muncă în căutarea unui serviciu mai bine remunerat. În ultimii ani, se poate observa cristalizarea unor comunități româneşti, în special în Italia, Spania, Franţa, Marea Britanie, formate din familii cu proprietăţi şi servicii stabile, care au învățat limba țării de adopție şi ai căror copii merg la şcolile locale. Aceste comunităţi formează parohii bine organizate şi cu posibilități financiare consistente şi joacă un anumit rol în structurarea vieții private, sociale şi publice a emigranților. Lor li sau adăugat, în special în Statele Unite ale Americii, în Europa Occidentală sau în parohiile din Japonia şi Australia unii cetățeni străini, convertiți la ortodoxie, care frecventează parohiile româneşti din străinătate. Datorită căsătoriei cu persoane ortodoxe sau a unor trăiri şi revelații personale, datorită confruntării cu lumea secularizată sau a unor experiențe nefericite din viața personală, în ultimii ani, multe persoane care nu sunt de naționalitate română s-au botezat şi au devenit membri ai parohiilor româneşti din diaspora.

În analiza fenomenului diasporic, putem distinge între emigranți pentru care orientarea spre România este dominantă, emigranți centrați pe societatea - gazdă, emigranți de orientare ambivalentă şi persoane care nu manifestă o loialitate teritorial -

${ }^{14}$ E vorba de comunitățile românești din Australia sau din țări europene precum Franța și Germania, în care românii sunt deja la a doua sau chiar a treia generație, au devenit cetățenii ai acelor state, însă de origine, limbă şi cultură română. Majoritatea parohiilor din aceste țări sunt mai vechi, au biserici proprii şi se administrează fără ajutor din țară.

${ }^{15}$ Pr. Ion Armaşi - Vartan, Biserica Ortodoxă Română în diaspora. Scurt istoric şi organizare actuală, Teză de doctorat, susținută la Facultatea de Teologie Ortodoxă „Justinian Patriarhul” din București în data de 22 noiembrie 2011, p. 302. 
națională bine determinată. ${ }^{16}$ Cei care au păstrat legătura cu țara şi se simt mai ataşați de țară şi păstrează credința, tradiții, limbă şi obiceiuri au un mod mai puțin structurat al modului transnațional. Ei locuiesc temporar în străinătate, însă sunt activi în expedirea de remitențe, au planuri de revenire în țară şi comunică intens cu cei de acasă. ${ }^{17}$

De multe ori, plecările în străinătate s-au făcut după o logică a rețelelor săteşti sau regionale. Aceste rețele au răspândit modelul prosperității şi, prin urmare, au antrenat şi satele vecine în mobilitate. Totuşi, aceste rețele şi-au orientat adesea fluxurile migratorii spre aceleaşi țări sau, mai exact, spre aceleaşi regiuni de destinaţie. Cel mai elocvent exemplu este Certege, o comună din Țara Oaşului, care a antrenat în mobilitate şi chiar în aceeaşi activitate peste hotare (vânzarea de ziare pe străzi) tpe oți țăranii din Oaş, cuprinzând şi oraşul Negreşti. Oşenii au constituit, începând cu 1994, o zonă în suburbiile din jurul Parisului. Cazul Certege nu este singular, seria de sate-pilon continuând cu Corod în regiunea Padova, Borşa la Milano, Sâmbăta de Sus la Roma etc. Cei plecați în străinătate din regiunile amintite mai sus au format comunităti stabile, cu multiple nevoi, printre care şi spirituale. $^{18}$

Foarte important de subliniat este faptul că lumile sociale ale migrației, ale celor ce temporar se află departe de țară, sunt formate nu numai din sentimente, trăiri, evaluări şi instituţionalizări ale emigranților, ci şi ale celor ce revin în România. De felul în care Biserica Ortodoxă Română se ocupă de nevoile lor spirituale şi îi spijină în experiența străinătății, poate depinde şi felul în care evoluează valorile celor care revin în țară, aducând străinătatea acasă. Indiscutabil, experiența de locuire în străinătate schimbă unele

${ }^{16}$ Dumitru Sandu, Lumile sociale ale migrației româneşti în străinătate, Ed. Polirom, Iași, 2010, p. 166.

${ }^{17}$ Ibidem, p. 167.

${ }^{18}$ Dana Diminescu, Exercitiul dificil al liberei circulatii. $O$ introducere in istoria migrației recente a românilor, în Remus Gabriel Anghel, Istvan Horvath (coord.), Op. Cit., p. 57. 
mentalităti şi percepții legate mai ales de muncă, toleranță, identitate spațială, reuşită în viaţă şi intenţionalitate de vot. ${ }^{19}$

Concluzionând, putem spune că în cadrul comunitătilor ortodoxe româneşti din diaspora, funcționează 13 eparhii şi aproximativ 700 de preoți, care îl propovăduiesc pe Hristos în limba română, pentru cei peste 4 milioane de români aflați la muncă în afara României ${ }^{20}$. Deşi „Ortodoxia în Occident rămâne o prezență discretă, care încearcă să explice mai bine lumii occidentale unele aspecte ale spiritualității sale: icoana, rugăciunea lui Iisus, liturghia bizantină" ${ }^{21}$, bisericile româneşti din diaspora nu sunt doar lăcaşuri de cult în limba maternă, ci sunt, am putea spune, mici Românii, unde „experiența transnaţională, diasporică, este percepută ca un continuum între spațiile de apartenență şi de afiliere"22, unde un tricolor împodobeşte icoanele sfinților români, sărbătorile sunt prilej de rugăciune, de anamneză identitară şi de sinceră comuniune.

Sfântul Sinod al Bisericii Ortodoxe Române, ca un semn de aprecire creştinească şi românească a românilor care lucrează sau studiază în străinătate, în şedinţa sa de lucru din 25-26 februarie 2009 a luat hotărârea ca, în fiecare an, prima duminică după sărbătoarea Adormirii Maicii Domnului (15 august) să fie celebrată ca Duminica românilor migranți, această duminică fiind înscrisă în calendarul bisericesc şi inclusă în programele liturgice şi pastoral-misionare ale fiecărei eparhii. Rostul principal al acestei duminici speciale din luna august, când mulți dintre românii plecați în străinătate se întorc acasă în concediu, este de-a spori comuniunea cu cei plecați, astfel ca munca sau studiul departe de țară, să nu devină îndepărtare sau înstrăinare spirituală față de românii de acasă, din aceeaşi familie sau din aceeaşi parohie.

${ }^{19}$ Dumitru Sandu, Op. Cit., p. 182-184.

${ }^{20}$ Patriarhia Română, Darea de seamă a Sectorului Comunităţi externe pentru anul 2012.

${ }^{21}$ Pr. Emanoil Băbuș, Ortodoxia națiunilor în Europa Occidentală, în vol. „Biserica Ortodoxă în Uniunea Europeană. Contribuţii necesare la securitatea și stabilitatea europeană", Ed. Universităţii din Bucureşti, 2006, p. 113.

${ }^{22}$ Camelia Beciu, Op. Cit. p. 59. 